\title{
Enigma Variations: Poetry and Modern Nightlife
}

\author{
Daniel Tiffany
}

Pitch

Taverns and nightclubs are places where casual social interaction, business, and even crime, coexist in a place governed ostensibly by pleasure. They are also sites where the illicit and often subversive habits (or "trades") of the demimonde become intelligible - and available - to members of law-abiding society. As a verbal site, a place in poetry, the topology of the nightspot has its origins in the drinking songs of the canting tradition. "Cant," the earliest term for slang in English, refers to the specialized jargon of the criminal underworld, employed by thieves, beggars, prostitutes, and vagabonds. Evident since the fourteenth century, a submerged tradition of poems written in canting speech has developed with increasing resonance, sometimes in conjunction with the dominant literary tradition. ${ }^{1}$ Cant is thus the idiom of a vernacular tradition embedded in the "flash crib," the place where flash talk, or cant, is spoken. The history of nightlife and the riddling speech of cant illuminate one another, blindly and reciprocally, disclosing precious details about phenomena that have nearly vanished from historical memory. In this sense, the rhymes of the canting crew (embedded in a variety of literary texts) function as sources of historical-and profane-illumination, fitfully and haphazardly lighting the topography of nightlife.

Daniel Tiffany is the author of Radio Corpse: Imagism and the Cryptaesthetic of Ezra Pound and Toy Medium: Materialism and Modern Lyric, the latter named one of the "Best Books of 2000" by the Los Angeles Times Book Review. The essay contained in this issue is excerpted from his latest critical project, Lost Laboratories of the Sphinx: Poetry, Philosophy, and Infidel Culture. Tiffany's debut collection of poetry Puppet Wardrobe is newly published by Parlor Press. 
The queer space of the nightspot, as it appears in the canting song, gradually develops into a literary, or poetic, topos, with recognizable contours. Not surprisingly, these lyrical habits often preserve historical features of the demimonde. Voices, never entirely real, rise out of the historical night, scant evidence of a culture lying just below the threshold of verisimilitude. The anonymous measures of the canting song contribute to our knowledge of places where history is made at night, but also to a literary topos, a place made of words, a placeless place, where history and poetry converge in the proverbial dark.

Among the works of the dominant literary tradition that might serve as a locus classicus of the poetics of nightlife (John Skelton's “Colin Clout” or François Villon's Ballades en jargon, for example), the most elaborate and notorious are the tavern scenes in Shakespeare's Henry IV, Parts 1 and 2 (and in Henry V as well). These rude tableaux de nuit offer what is essentially a prehistory of modern nightlife. Not simply a place of intoxication and illicit, or even criminal, activities, the tavern in these scenes is a refuge where people of different social classes, vocations, and sexual persuasions mingle apart from the stratification of the world in daytime. In the tavern, a prince rubs shoulders with thieves, whores, and pimps; the world encounters the demimonde. As a site of social experiment and dissolution, the tavern or club proves to be an enigma to the rationalized and productive world from which it is deliberately concealed by its nocturnal hours and often unfamiliar location.

From the text of the tavern scenes in Henry $I V$, one learns, at the very least, a great deal about the material culture of nightlife in the Elizabethan period: the kinds of food and beverages consumed; the cost of such items (one scene ends with a tally of Falstaff's bill); the availability of credit to customers; the tradespeople involved in the business (hostess, vintner, "drawer," etc.); the role of itinerant musicians; the naming of private rooms within the tavern (such as the "dolphin" or "half-moon" rooms); the use of "links" for street lighting; the hours of operation (often very late-several scenes don't begin until after midnight and end with breakfast being served shortly before dawn).

As rich as this material may be, the most substantial and memorable insights gained from these scenes concern the types of people apt to be found in a tavern late at night, the nature of their social bonds, and - of course - the way people talk in such places. Indeed, because language happens to be, in this case, the very medium of the profane dream of nightlife, it is not surprising that the way people talk comprehends the hermetic world of the tavern. Inevitably, the reader (or spectator) is both amused and puzzled by the tavern talk of Falstaff, Pistol, Bardolph, Mistress Quickly, Doll Tearsheet, and other pseudonymous figures of the demimonde in the chronicle plays. For the queer language of the tavern is distinguished by its general obscurity, by wordplay of all kinds, by the rhetoric of cursing and malediction, and by abundant use of slang words. In this regard, tavern talk recalls (and employs) many features of the canting song, even as it anticipates the riddling speech of Shakespeare's later plays. One could even say that the intense lyricism of tavern talk brings to mind a kind of poèsie pure associated with literary modernity.

The tavern scenes in Shakespeare raise important questions about the context of the riddling speech of nightlife. Could we say, for example, that the profanity of 
tavern talk - perhaps its most common feature in Shakespearean nightlife-somehow renders the social, topographical, and even architectural obscurity of the tavern? To put it another way, could the "pattering flash" of Pistol, Falstaff, and Doll Tearsheet be understood as an expression of the illegitimacy of nocturnal culture? It is possible that the insular nature of Falstaff's "flash" talk somehow models the inscrutability - the material secrecy — of the nightclub?

We can be certain that Prince Hal views his association with "the good lads of Eastcheap" as something resembling an honorary membership in the fraternity of the canting crew. For he says,

I have sounded the very base-string of humility. Sirrah, I am sworn brother to a leash of drawers [tapsters]....They call drinking deep "dyeing scarlet"; and when you breathe in your watering, they cry "hem!" and bid you "play it off." To conclude, I am so good a proficient in one quarter of an hour that I can drink with any tinker in his own language during my life. (Henry IV,Part 1,2.4.5-19)

The prince refers here not only to a drinking game called "dying scarlet," but to the oaths and cant songs accompanying the game: "I can drink with any tinker in his own language." He claims to be a quick study, and the colorful nature of his speech throughout the scene bears him out. It's no mystery where the prince would have learned so well to swear and boast in canting speech; one need only attend to the "pattering flash" of the rogues around him. Here, for example, is Doll Tearsheet abusing poor Pistol: "Away, you cutpurse rascal! You filthy bung, away! By this wine, I'll thrust my knife in your mouldy chops an you play the saucy cuttle with me. Away, you bottle-ale rascal! You basket-hilt stale juggler, you!" (Henry IV, Part 2, 2.4.126-129). Doll belongs to the marginal world of the canting crew, and her speech, as this passage reveals, contains a higher percentage of cant vocabulary than that of any other character. But all of the characters, including the prince, are familiar with thieves' latin to varying degrees.

In act 2, scene 4 of Henry $I V$, Part 1 , the sociological and verbal substances of this degraded yet lyrical precinct are captured in a single, material trope. At one point, Hal asks Falstaff to play-act the role of his father, the king, in order to interrogate him (the prince) concerning his association with the canting crew and his wayward habits. Falstaff holds forth:

Shall the blessed sun of heaven prove a micher and eat blackberries? A question not to be asked. Shall the son of England prove a thief and take purses? A question to be asked. There is a thing, Harry, which thou hast often heard of, and it is known to many in our land by the name of pitch. This pitch, as ancient writers do report, doth defile; so doth the company thou keepest. (Henry IV, Part 1,2.4.404-411)

The dark substance of pitch represents here the various kinds of obscurity associated with the tavern: its nocturnal hours and notorious location; the derelict company of harlots and thieves; the verbal filth of thieves' latin ("the name of pitch"). 
The pitch of each of these phenomena defiles the prince, which is precisely why one must not pose the question, "Shall the blessed sun of heaven prove a micher and eat blackberries?" In this form, the question is defiled by canting speech: "micher" is a cant word for thief, and "to eat blackberries" means to do nothing, to waste one's time. Evidently, the inky substance of the blackberry incorporates a trifling matter into the metaphor of "pitch," so that the blue-black substance of cant - its queer music_-defiling the mouth appears to be evidence of petty theft. Only several lines earlier, Falstaff refuses to explain his ridiculous behavior in a bungled theft by declaring, "Give you a reason on compulsion? If reasons were as plentiful as blackberries, I would give no man a reason under compulsion, I" (Henry $I V$, Part 1,2.4.236-238). Certainly, the contaminating verbal substance of the blackberry, like the defiling "pitch," has its "reasons," however difficult they may be to extract from the ragged speech of the canting crew.

Judging from the texts I've examined here, the poetry of the topos of nightlife is not uniformly obscure; rather, it is variable and heterogeneous. In Shakespeare's tavern scenes, different characters use varying amounts of slang and speak with various degrees of clarity or intelligibility, ranging from the color and profanity of Doll Tearsheet's speech to Prince Hal's occasional show of courtly diction. Even the expression of individual characters is variable and unstable, sliding easily between different registers of jargon, colloquial, and conventional speech. One finds the same variability of tone in the canting song, which can incorporate different voices and modulate the thickness of its "pedlyng french." In Shakespeare's tavern scenes, Falstaff is the most volatile figure verbally, capable one moment of speaking like a gentleman and, at the next, of cursing like a rogue. Prince Hal, too, as he himself likes to boast, can talk like one of the canting crew when he wishesthough his tone is less erratic than Falstaff's. This variability suggests that, for many of these characters (and indeed for the speakers of the canting song), jargon or canting speech is never unadulterated and can be easily adopted or discarded, once it is learned, like a mask. Indeed, impersonation and role-playing are common features of the conduct in the tavern scenes, suggesting that verbal - or poeticobscurity involves elements of craft, artifice, and transformation.

In addition, the heterogeneity of tone evident among (and within) different voices betrays verbally the principal social function of the club as a rendezvous for disparate-and often notorious - elements of society. Although the club may be concealed from society at large, it is nevertheless the place where one goes to find individuals who may be otherwise difficult or impossible to find-either because they have no stable residence or because they are obliged to conceal their whereabouts. Hence, though the club may be a place to do business in public without getting busted, or a place to rob and cheat - all in the name of pleasure - it is also, for these reasons, a magnet for the police. In Shakespeare, the sheriff and his deputies, "Fang" and "Snare," repeatedly descend on the Boar's Head Tavern, trolling for suspects. From its origins as a topos in canting literature, the tavern has always been a refuge of sorts, a place to which the "quier-coves" (wise guys, in canting parlance) retire (to party) after a night of burgling houses or picking pockets. Such is the case in Henry IV, Part 1, when Falstaff and his crew retire to the 
Boar's Head after bungling a robbery, where the prince is waiting for him.

As a social space, the tavern is fluid, promiscuous, and highly contingent: the sheriff drops by, looking for suspects in a robbery; the prince waits for Falstaff to show up; and representatives of the king come by periodically, searching for the prince, to remind him of his duties. In this respect, the social space of the tavern, like its verbal substance, is at once open and closed, flagrant and secretive: an open secret. Within the queer ken of the nightspot-within its jargon and within language itself - the speaker always seems to lie just beyond the reach of the world and its appointments, its duties, its certainty. Considering the topological character of nightlife, it seems quite reasonable to suggest that this queer space (and its false immunity) reflects the nature of the lyric stanza and its tenuous substance. Further, one could therefore argue that the social contingencies and heterogeneity of nightlife reflect back to us the nature of poetic expression and lyric substance.

\section{Noctambulism}

The hermeticism of the nightspot was first breached from within, by inscription, by songs written in the jargon of thieves and by a kind of shorthand (the writing of spies and police informants). As such, public knowledge of the topology of nightlife was, from the start, intrinsically lyrical and unavoidably sentimental-because it was caught, unalterably, in the ambiguity of verbal reflection. Thus, insofar as the siren song of nightlife - a kind of beggar's chant - reaches the ears of those outside the secret society of the demimonde, then nightlife becomes an open secreta demonstration of the enigma of sentimentality. Yet the scale and effect of this irremediable disclosure underwent a transformation when the topos of the nightspot incorporated the technical medium of print during the French Revolution and when the substance of nightlife-its codes and desperate measures--became overtly politicized. At that point, the dissemination of the lyric substance of the demimonde began to occur on a massive scale, which marks the beginning of modern nightlife.

In 1814, a new technology appeared which dramatically altered and accelerated the reformation of nightlife already initiated by the revolutionary coupling of tavern life and print culture: the installation of the first gas lamps in the streets of London (Schivelbusch 111). The use of gaslight in public places, which was widespread in Paris and London by the 1840s, expanded from street lamps to the illumination of shops and taverns. The spectacle of entire cities illuminated at night by artificial light drew crowds into the streets after dark, initiating what Walter Benjamin has called "the great era of noctambulisme" (Benjamin, "The Paris of the Second Empire in Baudelaire," 50). Large numbers of people, dazzled by the effects of artificial light flooding the city at night, wandered the streets for hours-like zombiespenetrating for the first time the dangerous quarters of the city after dark. Contemporary descriptions frequently characterized the nocturnal spectacle in reference to some sense of interiority; one observer in 1854 described the scene as "always festively illuminated, golden cafés, a stylish and elegant throng, dandies, literati, financiers. The whole thing resembles a drawing room" (qtd. Schivelbusch 148149). Another observer, in 1861, commented on the "glittering shops everywhere, splendid displays, cafés covered in gilt, and permanent lighting.... The shops put 
out so much light that one can read the paper as one strolls" (qtd. Schivelbusch 152). Interestingly, the aspects of interiority evoked in these passages (including the double retirement of reading) cannot be compared to that of the domestic interior, since gas lighting in domestic spaces lagged well behind its appearance in public places. Indeed, interiority in this context has little to do, really, with the insides of buildings in any conventional sense. Rather, it is a new form of interiority - a form of inwardness, properly speaking - which combines a startling element of publicity with the sense of closure intrinsic to the topos of the nightspot. In the era of modern nightlife, the veil of secrecy and the aura of publicity are one and the same.

Though ostensibly unrelated to the philosophical and representational engines of the Enlightenment (libertine rationalism and the printing press) revising the topology of nightlife, the installation of street lamps in fact hastened-and reversed - the social transactions precipitated by revolutionary means, by forms of rationalization that were more overtly politicized than the neutral medium of gaslight. For the increased public security afforded by streetlights made it possible, as I have indicated, for the middle and upper classes to safely visit the realms of the demimonde, to haunt the topology of the dangerous classes. The influx of so-called honest society into the "queer" sites of the demimonde reversed, or reciprocated, the transfusions of social (and literary) capital from the underworld to society at large. Now, the topology of nightlife (the realm of infidel society) was breached not from within but from without.

Setting in motion these topographical exchanges, the sudden illumination of nightlife prompted as well certain temporal reconfigurations which were played out, like their spatial counterparts, in terms of class conflict:

Court society had underlined the distance separating it from the bourgeoisie by ostentatiously keeping late hours, day and night. Now the middle classes tried to distance themselves from the petty bourgeoisie and the artisan class in the same way. The later one began the day, the higher one's social rank. Consequently, everything began to happen later and later. (Schivelbusch 140)

By producing an artificial regime of belatedness in public leisure, and by dispersing the literal darkness of certain quarters that had always harbored the most dangerous elements of society, the industrialization of light (amounting, quite literally to the industrialization of Enlightenment) advanced and elaborated, irresistibly, the rationalization of nightlife. ${ }^{2}$

It was no accident that the term "slang" (a cant word) came into general usage during the "era of noctambulisme," as cant was evolving from a restricted verbal practice (the secret jargon of a closed community) into a more widespread phenomenon of illegitimate speech supplementing, and sometimes eroding, standard linguistic usage. Thus the alien tongue of the underworld lost some of its insularity and obscurity - its "queer" identity — as the industrialization of light permitted the middle classes to penetrate (as pleasure-seekers) the secret topography of the demimonde. 


\section{Tingeltangel}

The first modern nightclub, the Chat Noir, opened in Paris (in Montmartre) in 1881. The habitués of the club were known as "les apachés," figures inspired by Baudelaire's "poetry of apachedom," of which examples (from Spleen de Paris) were recited, or set to music, at the Chat Noir (Fields 15-16). ${ }^{3}$ Indeed, the literary inspirations for the Chat Noir encompassed its basic orientation and milieu: the club presented itself as a cabaret artistique, a new kind of public meeting placeat least in the initial stages of its operation - for writers and artists (for a group of poets, in particular, known as the Hydropathes). In essence, the Chat Noir stagedin a deliberately flamboyant manner - the integration of the artist (as a social outcast) into the gallery of criminals, revolutionaries, and libertines long associated with the underworld of taverns and secret clubs. Though criminal and political elements were peripheral to the operation of the Chat Noir (and though it was hardly a clandestine operation), the new topos of the nightspot cultivated an alluring, if deceptive, alliance between the "artist" and infidel society. The commercial and aesthetic appropriation of infidel culture thus became not only one of the distinguishing features of modern nightlife, but a prototype for the evolving ideology of the avant-garde.

It is essential to bear in mind that the first modern night club, the cabaret artistique, was simultaneously the culmination of an evolving apparatus of sentimentality, which had been mapped onto the topology of nightlife during the nineteenth century, and an authentic locus of adversarial culture. Publicity became an integral part of the various registers of obscurity (sociological, literary, even architectural) associated with the topology of nightlife. Almost as soon as the Chat Noir opened in 1881, Rudolphe Solis (its founder and proprietor) turned the club into a commercial venture, in part to advance the careers of writers and artists associated with the club. Following the precedent established by the ultra-radical underworlds of Paris and London (though with entirely different objectives), the Chat Noir quickly exploited the medium of print to disseminate its brand of bohemianism and the ephemeral productions of its stable of artists and poets (most now forgotten). Only a month after it opened, the club began publishing its own weekly journal (in tabloid format), with a print run that grew from 300 to 20,000 copies per week in a matter of seven years (Fields 23). A quarter of the four-page tabloid was given over (on its back page) to advertisements for local merchants and theaters, but also for the Eiffel Tower and various International Expositions. Resembling a modern publishing enterprise, the stable of Chat Noir publications quickly grew to include the Chat Noir Guide (a brochure for the club listing the art works on view - for saleat the club); the Album du Chat Noir (a portfolio of drawings to be sold by subscription); song sheets of lyrics recited or sung at the club; Contes du Chat Noir (stories and illustrations by club favorites); and theater programs for the famous shadow plays performed at the club (Fields 28). The Chat Noir, whose success prompted it to move to three successively larger venues in the course of its operation (it closed in 1897, shortly after Solis died), spawned numerous imitations in the cities of Europe and America. Exploiting the new nocturnal mobility made possible by the installation of street lamps, the publicity generated by the club's print appa- 
ratus drew large numbers of the bourgeoisie to its marginal location in Montmartre, to what was essentially a commodification of infidel society, a calculated spectacle of bohemianism. The practice of "slumming" - of middle-class city dwellers visiting self-consciously seedy clubs in marginal neighborhoods - became a powerful ingredient in the allure of modern nightlife. Walter Benjamin called his frequenting of clubs and cafés a "daily need" and "a vice" - perhaps acknowledging the false consciousness which had come to occupy the topology of nightlife (Benjamin, "A Berlin Chronicle," 21).

The appeal of a fraudulent underworld was especially strong in clubs which cultivated a deliberately coarse and promiscuous atmosphere. In Berlin, disreputable "joints" of this kind were known as Tingeltangel clubs - a nonsense word ( similar to the American "honky-tonk") evoking lewd or rowdy behavior, but also, perhaps, the sound of coins dropping into a collection plate passed around-along with dirty postcards for sale - between sets at a cabaret. The seedy atmosphere of the Tingeltangel club (including the latter two customs) is memorialized in the tavern scenes of Josef von Sternberg's film The Blue Angel (1931). ${ }^{4}$ The tawdry club in the film, as well as Marlene Dietrich's performance as a smutty chanteuse, were modeled on historical Tingeltangel clubs such as The Hungry Pegasus (opened in Berlin in 1901), where one could see, for example, performances by a poet (under the pseudonym "Dolorosa") "who recited erotic and sadomasochistic verses," or artists performing what reviewers invariably referred to as "niggersongs" (evidence of the contemporary infatuation with African-American music) (Jelavich 86). With an audience, according to one observer, consisting of "artists and scholars, writers and financiers, ladies of the best society and piquant bohemiennes," The Hungry Pegasus was essentially "a place where middle-class citizens could observe, and even pretend to be, bohemians" (Jelavich 87).

Slumming - in many forms and permutations - in modern nightlife can be regarded as a ritualization of the enigma of sentimentality lying at the very core of the relation between nightlife and poetry. As the performative and emblematic properties of the word Tingeltangel suggest, the discourse of slumming in modern nightlife often has a verbal component. That is to say, in regard to the problematic of sentimentality, one may be lured back into an underworld that no longer possesses distinct physical limits by certain verbal resonances-by poetry. Evidence of the Orphic (or perhaps Ariadnean) aspect of poetry's relation to modern nightlife can be detected in the configuration of the speakeasy-a secret club unlocked by a secret word. Yet evidence of the modern Opensesame! principle can also be found, more graphically, in clubs evoking elements of infidel society which had shunned the new publicity of the underworld. For example, a club called Le Mirliton (an argot word meaning either a reed flute or doggerel verse) opened in Paris in 1885 in the old premises of the Chat Noir; its owner, Aristide Bruant, composed and sang verses in Parisian argot - "accusatory songs that deplored the fate of workers, criminals, and the poor" (Jelavich 26). Similar clubs, atavistic in nature, occupied an important niche (related to the Tingeltangel) in Berlin as well. Police records-we are once again back in the realm of spies and informants - monitored closely the performance of Hans Hyan, the owner of The Silver Punchbowl (which opened in Berlin 
in 1901) - not to mention the performances of "Dolorosa," who had taken her sadomasochistic act (including "The Song of Songs of Pain and Torture") to The Silver Punchbowl (Jelavich 90). In any case, Hyan, who had a rather extensive criminal record (robbery, aggravated burglary), was considered to be "the Berlin counterpart to Aristide Bruant" (though he sounds a bit more-dare I say it - authentic): "he possessed an exceptional ability to imitate the speech of various social groups in Berlin, in particular the slang of the downtrodden and criminal classes.... At the moment [one reviewer wrote] there is probably no other author who has such a masterful command of the Berlin dialect and of the argot of the criminal underworld" (Jelavich 89). Whether or not Hyan's renditions of Berliner canting speech were "imitations" or not, he certainly convinced the police of their authenticity: they shut down his club for good in 1904 (Jelavich 90). The very question of whether his canting songs were imitations or not underscores the problem of sentimentality in modern nightlife, though it does not detract from poetry's ineluctable role in conveying the many forms of obscurity comprising the partial world of the demimonde.

Slumming, as the use of slang in certain clubs reveals, can affect a pungent lyrical accent, yet these social migrations also leave legible traces in the architectural configuration of early modern nightclubs and in the interior design and furnishings which play such an important role in establishing the atmosphere of a vanished underworld. One might therefore pay closer attention to the "interior design" of early modernism - including what appears to be a dangerous concoction of kitsch and avant-garde props - especially in places, like nightclubs, which have been seriously overlooked by architectural historians. Seeking to establish the broadest possible perspective on such matters, historian Peter Jelavich develops an interesting argument concerning the formal correspondences between the eclecticism of cabaret and the modernist ideologies of collage or assemblage (Jelavich 19). He calls cabaret a form of "metropolitan montage," though he misses a more seductive and philosophically-informed genealogy of fragmentation: Weimar songwriter Friedrich Hollaender identified the "aphoristic novel" as "the secret of cabaret," alluding to Friedrich Schlegel's conception of the ideal-and therefore unattainable - form of poetic-philosophical discourse (Hollaender 566). ${ }^{5}$ The link between cabaret and the Jena Circle is not as far-fetched as it might seem, since Nietzsche's vitalist philosophy was touted as one of the inspirations for the "literary vaudeville" of cabaret. The very first cabaret in Berlin, the Motley Theater (opened in 1901), had a bust of Nietzsche in its foyer and was often referred to as the Überbrettl, a neologism combining Übermensch and Brettl (stage boards) (Jelavich 29). In another example of cabaret's infatuation with Nietzsche, Mary Wigman (the pioneering expressionist dancer) performed a dance piece to a recitation of Nietzsche's Thus Spake Zarathustra at the Dada Cabaret Voltaire in Zurich in 1917 (Manning 69-69). Yoking together Nietzsche and vaudeville (or expressionist dance) exemplifies the collision of high and low cultures in the experimental milieu of modern nightlife. The social bric-a-brac characteristic of the after hours scene (a modern invention) insists on reproducing itself as well in the layout and furnishings of the modern nightclub. In terms of interior design, slumming implies the importation of certain luxuries into the typically degraded environment of the 
tavern. Luxury in this context would therefore pertain to the category of portable or nomadic furnishings - regardless of stylistic gravities. Space in the Chat Noir (which had three floors, like many of today's more luxurious clubs) unfolded with a kind of institutional eccentricity: a tavern-like space on the ground floor; a theater for the famous shadow plays on the second floor; and L'Institut (or VIP Room) on the third floor, where the Chat Noir regulars planned the night's activities and prepared materials for the cabaret's journal (Fields 18-19). A stricter segregation of vulgar and ethereal environments could be found at other clubs, such as the Café Guerbois, which had "two rooms: a white and gold outside room, described as a terrace, and an inside room, described as a 'crypt,' with a low ceiling" (Fields 9). The designation of the "white and gold outside room," which recalls references to "golden cafés" and "cafés covered with gilt" in the first, infatuated decades of gaslight, records for posterity the newly sublimated substance of nightlife.

Though it would be tempting to pursue the architectural figures of the "crypt" and the "gold room" into a full-blown differentiation between high-life and low-life in nocturnal culture - as does later occur in modern nightlife - and to discover (in the age of cinema) the luminous half-life of the nightspot glittering in the shadows of film noir, I want to linger a bit longer over the interior-decorating skills of the incipient avant-garde. Who would have guessed that their taste in wall coverings, light fixtures, and linens could tell us something about the underside of modernism? Here's a glimpse of what Jelavich would call the "metropolitan montage" of the Chat Noir:

The interior of the Chat Noir was decorated seemingly at random. In reality, the cabaret's environment had been carefully planned by Solis and his colleagues. It featured furniture and artifacts of the Louis XIII period but in such humorously grotesque settings as to make them incongruous. Walls were covered with green wallpaper or green drapes. Paneling was made with glazed doors of Louis XIII design. On all available wall space were hung paintings, drawings, and prints created by the cabaret's resident artists. Crowds of pots, plates, medieval armor, and other assorted bric-brac hung from the ceiling or were stacked on any available flat surface. (Fields 12)

The rooms were lit - or halflit - anachronistically, it should be noted, with candelabra and wrought-iron chandeliers casting shadows on fashionable Japanese screens. Aside from the peculiar custom of "resident artists" decorating the club (is this the beginning of installation art?), one notes the horror of empty space and surfaces; the superabundance of what Walter Benjamin would call the "trash of history" (from which one composes "dialectical images"); and the heavily ironized condition of certain pieces (such as the second empire furnishings) competing for space with the "resident" art. All in all, the haphazardness of object relations in the first modern nightclub appears to have been fueled by a kind of sadism. And one should not overlook the fact that the green drapes (resembling, perhaps, the green billiardcloth trousers favored by bohemian dandies of the period) were hung to cover the rough limestone walls of a former post office (Fields 12). 
The popularity of the Chat Noir in Paris turned into a kind of franchise operation, with imitations of the club, sometimes including the name itself, sprouting across Europe for more than a decade after the demise of the Parisian club in 1897. Norway, for example, opened its Chat Noir in Kristiania before London christened its own version of the club in 1912, the Cave of the Golden Calf, named after one of the rooms in the Parisian Chat Noir. ${ }^{6}$ Founded by Frida Strindberg (the former wife of the playwright, August Strindberg), the Cave of the Golden Calf served as the after-hours headquarters for what would become London's first avant-garde movement, Vorticism, which offered a new and more militant platform for the Imagist group of poets (the first organized expression of Anglo-American poetic modernism). Thus one could plausibly argue that the avant-garde in London (in the form of the Vorticist movement) was born in a nightclub. In addition, the Cave of the Golden Calf (which was founded the same year as the Imagist movement in poetry) furnished a dialectical space-its secrecy was a form of publicity - for the first attempts at modernist experimentation in poetry. Thus the evolving topology of nightlife was providing, as it had so often in the past, a clandestine space (now dialectically publicized) for illegitimate or provocative forms of lyric expression, and for social and cultural experimentation. Orpheus was once again revisiting and making songs about (and thereby making public) a floating "party" in the underworld.

But what kind of underworld was this space, defined by its late hours and by its belatedness, in London in 1912? What can we learn about the infidel aesthetic of Vorticism by examining the interior design of this improvised club - it stayed open only 18 months - housed in a large basement below a warehouse off Regent Street? Concerning the original premises, Frida Strindberg wrote, "It was naked and cold with no tables or chairs, with mortar and limestone dust everywhere. It looked like a construction site or a ruin" - a "decor" still in vogue to this day in the architecture of nightlife (Strauss 179). To decorate the place and provide entertainment, Strindberg gathered around her a stable of "resident" artists and writers, including Wyndham Lewis, Jacob Epstein, and Ezra Pound, who remembered the Cave of the Golden Calf as "the only night club (one of the first in London) which impoverished artists cd/get into" (qtd. Mullins 99). The "Preliminary Prospectus" for the club (illustrated with woodcuts by Wyndham Lewis) claimed the cabaret would "do away with the necessity of crossing the channel to laugh freely and sit up after nursery hours" (Strauss 175). As this comment suggests, the Cave of the Golden Calf looked to the Chat Noir for inspiration, borrowing its name and a singer named Bokken Lassen, who had performed at the Überbrettl in Berlin and the Chat Noir in Kristiania (Strauss 178). Wyndham Lewis produced a variation of the shadow plays made famous at the Chat Noir in Paris. In addition, the Cave of the Golden Calf opened only three months after Marinetti's first visit to London, which gave added impetus (and a Futurist slant) to Frida's plans for the club.

The experience of the Cave of the Golden Calf was thoroughly contrived, including a full panoply of printed ephemera: from the "Preliminary Prospectus" to programs, announcements, and menus - all designed in the latest cubist/expressionist style by Wyndham Lewis (who also created murals for the walls). The sculptor Jacob Epstein transformed "the cellar's structural columns into the painted plaster 
totem poles described by Ford Madox Ford in his novel The Marsden Case as "white caryatids with heads of hawks, cats, and camels picked out in red" (Strauss 177-78). Opening night saw performances by singer Bokken Lasson, shadow plays by Wyndham Lewis, an actor reciting Oscar Wilde's fairy tale (for adults), "The Happy Prince," and "a young man with a cockney accent" abusing the audiencein true cabaret fashion (Strauss 179). The club was known to offer an "artist's meal" (according to the "Preliminary Prospectus") and reduced admission to "the youngest and best of our contemporaries and Futurists" (Strauss 175, 179). (At the same time, Pound suggested the club was "probably also an outpost for espionage" [Mullins 99]). As a kind of soup kitchen (and showcase) for the avant-garde, the Cave of the Golden Calf presented an amalgam of dated Symbolist cartoons and cutting edge material associated with various infidel causes. (Oscar Wilde's "The Happy Prince" qualifies as an example of both of these categories.) Sir Osbert Sitwell remembered "a super-heated garden of gesticulating figures, dancing and talking, while the rhythm of the primitive forms of Ragtime throbbed through the great room" (Strauss 180). Yet one could also order cold lobster salad at the first modern nightclub in London.

In the end, the Cave of the Golden Calf offered a distinctive example of what Jelavich calls the "metropolitan montage" of modern nightlife, possessing qualities that Ford Madox Ford captured superbly in an apology for Strindberg's ephemeral project:

Poor Madame S. - try to bear with her. She is trying to build up a Palace of all the Arts with three oyster shells and stale patchouli and sawdust and crème, the buttons off waiter's waistcoats, champaign corks and vers libre - which is what - including typewriters which go wrong and produce palimpsests - we are all of us trying to do in one field or the other. (qtd. Strauss 182)

The performative and aesthetic "palimpsest" of modern nightlife expresses a sociological phenomenon associated specifically with the conditions of nocturnal culture: transient (and transitive) exchanges between disparate classes, races, genders, and sexualities. I have emphasized nightlife's effect on the erosion of class identities and the practice of slumming: the descent of the middle classes - for purposes of recreation - into the milieu of a criminal and indigent underworld (a milieu appropriated and aestheticized by various artistic movements). Unlike the rationale for the hermetic sites of the criminal or political underworlds, the verbal, cultural, and topographical transgressions associated with class promised a night of "fancy milling" in a secret placeone of the invariable features of nightlife, it seems - that is, the prospect of mixing with people - with strangers - of different persuasions.

My emphasis on class has come, unfortunately, at the expense of discussion about certain kinds of contact between races, or among individuals of various sexual persuasions, which could occur only in the clandestine and socially unrestricted milieu of the nightclub. I have neglected, for example, the history of "black and tan" clubs (places where blacks and whites could mingle freely), not to mention the "white pilgrims" of the Harlem Renaissance - phenomena which would reveal an important racial dimension to the topology of nightlife. ${ }^{7}$ In addition, I have not 
been able to attend carefully to what may be the most distinctive social feature of modern nightlife: the opportunities for women, single or married, to circulate without male chaperones or companionship in complex and often unrestricted social environments.The liberality of these conditions for women led to often hysterical responses on the part of public officials and patriarchal society. A public campaign against "tango pirates," "social gangsters," and "white slavers" developed in response to the imagined dangers (especially the specter of lower-class, non-white males) threatening white women in the unsupervised space of nightlife (Erenberg 83-86).

In the many covert forms of social exchange and migration I have examined in this essay, poetry played an essential role in modeling and disclosing the configurations of obscurity essential to the clandestine - and heterogeneous - community of nightlife. In the most radical sense, the pockets of social integration made possible by the secrecy of the nightspot (which functions simultaneously as a mode of publicity in modern nightlife) led to new formations of anonymity recalling the hermeticism intrinsic to the origins of nightlife - to phenomena such as Cabaret of the Nameless (Kabarett der Namenlosen), a club opened in Berlin in 1928. In a format resembling The Gong Show, or the more lurid talk shows on television today, the Cabaret of the Nameless offered a platform for private citizens (most without talent or training of any kind) to perform acts and recount stories of "helpless imbecility" (Kastner 562). The namelessness of the performers, who were indistinguishable from the patrons of the club, became the focal point of public visibility, thereby wrenching to its most extreme point what I have called the enigma of sentimentality. This dialectic of anonymity and publicity, of inwardness and exposure, became evident as well in contemporary reactions to the club, which, on one hand, was described as "a padded cell for the metropolis" (in which people "subject themselves to a psychoanalytic cure") and as a modern version of the Roman Coliseum: "The arena has become a cabaret. Armed conflict has turned into recitations" (Kastner 563).

Though the exhibition of namelessness may appear to be a specifically modern formation of sentimentality, it subscribes in many ways to the logic of the open secret which has characterized the topology of nightlife since its historical inception. Siegfried Kracauer understood Josef von Sternberg's film The Blue Angel to be an instance of what he calls "the appearance of lost inwardness" - a phrase that may be applied as well to nightlife itself (Kracauer 631). Strictly speaking, the appearance of "inwardness" in the external world - that is, the appearance of phenomena at odds with the "laws" of the visible world-is an impossible event, a contradiction that produces the intrinsic obscurity of nightlife (its location, its language, its social composition). As a form of inwardness, the nightspot appears in the world, though it seeks to erase, or obscure, any trace of that manifestation: it is an open secret, a productive paradox. And the dialectic of obscurity-Milton called the light of the underworld "darkness visible" - is precisely what aligns nightlife historically and conceptually with lyric poetry. For poetry as well may be described as "the appearance of lost inwardness"- an impossible event yielding unmappable places and queer combinations of social being. From the very beginning, we have known that Orpheus couldn't turn his back on the underworld and that by turning back he drew the gaze of those living in the upper world to the lyrical 
topos of the underworld. We have not sufficiently understood however that the underworld is indeed a historical place, even if the ambiguity of its material conditions cannot be isolated from the substance of poetry.

\section{Notes}

${ }^{1}$ For a theoretical and historical consideration of the poetics of the canting tradition and its significance for conceptions of lyric communicability, see my essay, "Fugitive Lyric: The Rhymes of the Canting Crew.” PMLA 120.1 (January 2005): 82-96.

${ }^{2}$ With the advance of lighting technology and the introduction of electric illumination in the 1880s, gaslight came to be viewed nostalgically by some observers, such as Robert Louis Stevenson, who described electric arc lighting as "A lamp for a nightmare! Such a light as this should shine only on murders and public crime, or along the corridors of lunatic asylums, a horror to heighten horror" (168). (R.L. Stevenson. "A Plea for Gas Lamps." The Biographical Edition of the Works of Robert Louis Stevenson [1905-1939]. Vol 13. New York: Charles Scribner, 1917.) Comments such as these make it clear that one should not think of artificial lighting as undifferentiated, either physically or ideologically. On the contrary, the material features of gaslight or electrical light would effect the topology of nightlife in diverse ways and therefore acquire distinctive ideological properties.

${ }^{3}$ Much of the historical material I present concerning the Chat Noir derives from the essays presented in Fields's exhibition catalogue Le Chat Noir. A Montmartre Cabaret and Its Artists in Turn-of-the Century Paris. For the broader context and insights into the European legacy of the Chat Noir, see Jelavich 26-27, 45-46.

${ }^{4}$ Friedrich Hollaender, who wrote the songs performed by Marlene Dietrich in The Blue Angel, founded the Tingel-Tangel cabaret in Berlin in 1931 (shortly after the film opened). Joining the German expatriate community in Los Angeles after fleeing Germany in the mid-1930s, Hollaender, one of the most gifted of the Weimar cabaret artists, tried to revive the Tingel-Tangel club in a location on Santa Monica Boulevard (in Los Angeles), a venture that quickly failed (Jelavich 2, 207, 258).

${ }^{5}$ Friedrich Schlegel's theory of "fragments," which led to the aphoristic composition of his novel, Lucinda (1799), is developed in the Athenaeum Fragments (1798). The most concise statement of his doctrine of poetry, fragmentation, and the novel (Roman/romantisch) appears in the famous Athenaeum fragment 116. See Friedrich Schlegel's Lucinde and the Fragments. Ed. Peter Firchow. Minneapolis: U of Minnesota P, 1971, 175-76.

${ }^{6}$ Reference to a stained glass window in the Chat Noir depicting the biblical narrative of the Golden Calf can be found in Fields, 18. The relation between the Chat Noir and the Cave of the Golden Calf receives some attention in Strauss, 178. Much of the information I present in this essay concerning the Cave of the Golden Calf derives from Strauss' biography of Strindberg.

${ }^{7}$ On the racial components of modern nightlife, see Erenberg 23, 73-74, 255-257.

\section{Works Cited}

Benjamin, Walter. “A Berlin Chronicle.” Reflections: Essays, Aphorisms, Autobiographical Writings. Ed. Peter Demetz. Trans. Edmund Jephcott. New York: 
Harcourt Brace Jovanovich, 1978. 3-60.

—. "The Paris of the Second Empire in Baudelaire." Charles Baudelaire: A Lyric Poet in the Era of High Capitalism. Trans. Harry Zohn. London: Verso Books, 1983. 11-101.

Erenberg, Lewis A. Steppin' Out: New York Nightlife and the Transformation of American Culture, 1890-1930. Westport, Connecticut: Greenwood Press, 1981.

Fields, Armond. Le Chat Noir. A Montmartre Cabaret and Its Artists in Turn-ofthe Century Paris. Santa Barbara, California: Santa Barbara Museum of Art, 1993.

Hollaender, Friedrich. "Cabaret” (1932). The Weimar Republic Sourcebook. Ed. Anton Kaes, Martin Jay, and Edward Dimendberg. Berkeley: U of California P, 1994.566-67.

Jelavich, Peter. Berlin Cabaret. Cambridge: Harvard UP, 1993.

Kastner, Erich. "The Cabaret of the Nameless" (1929). The Weimar Republic Sourcebook. Ed. Anton Kaes, Martin Jay, and Edward Dimendberg. Berkeley: U of California P, 1994.562-563.

Kracauer, Siegfried. “The Blue Angel” (1930). The Weimar Republic Sourcebook. Ed. Anton Kaes, Martin Jay, and Edward Dimendberg. Berkeley: U of California P, 1994. 630-631.

Manning, Susan. Ecstasy and the Demon: Feminism and Nationalism in the Dances of Mary Wigman. Berkeley: U of California P, 1994.

Mullins, Eustace. This Difficult Individual Ezra Pound. New York: Fleet, 1961.

Schivelbusch, Wolfgang. Disenchanted Night: The Industrialization of Light in the Nineteenth Century. New York: Oxford, 1998.

Schlegel, Friedrich. Friedrich Schlegel's Lucinde and the Fragments. Ed. Peter Firchow. Minneapolis: U of Minnesota P, 1971, 175-76.

Shakespeare, William. Henry IV, Part 1. Ed. David Bevington. The Complete Works of Shakespeare. $4^{\text {th }}$ ed. New York: Longman, 1997.

- . Henry IV, Part 2. Ed. David Bevington. The Complete Works of Shakespeare. $4^{\text {th }}$ ed. New York: Longman, 1997.

Stevenson, Robert Louis. "A Plea for Gas Lamps." The Biographical Edition of the Works of Robert Louis Stevenson [1905-1939]. Vol 13. New York: Charles Scribner, 1917.

Strauss, Monica. Cruel Banquet: The Life and Loves of Frida Strindberg. New York: Harcourt, 2000. 